\title{
Challenges and Opportunities for Telecommuting in the School System: Building a Sustainable Online Education in the Context of the SARS-Cov-2 Pandemic
}

\author{
Corneliu C. Simuț ${ }^{1}$, Laurențiu Petrila ${ }^{2,3, *}$, Felix-Angel Popescu ${ }^{3,4}$ and Ionuț Mihai Oprea $^{5}$ \\ 1 Department of Historical and Systematic Theology, Faculty of Theology and Religion, University of Pretoria, \\ Pretoria 0028, South Africa; corneliu.simut@gmail.com \\ 2 Doctoral School of Sociology, University of Oradea, 410610 Oradea , Romania \\ 3 Faculty/Department of Juridical and Administrative Sciences, Agora University of Oradea, \\ 410610 Oradea , Romania; felixangelpopescu@gmail.com \\ 4 Doctoral School of Economic Sciences, University of Oradea, 410610 Oradea, Romania \\ 5 Department of Sociology and Social Assistance, Faculty of Socio-Humanistic Sciences, University of Oradea, \\ 410610 Oradea, Romania; oprea_ionut_mihai@yahoo.com \\ * Correspondence: lauren.petrila@gmail.com
}

\section{check for} updates

Citation: Simuț, C.C.; Petrila, L.; Popescu, F.-A.; Oprea, I.M. Challenges and Opportunities for Telecommuting in the School System: Building a Sustainable Online Education in the Context of the SARS-Cov-2 Pandemic. Sustainability 2021, 13, 10296. https://doi.org/ $10.3390 /$ su131810296

Academic Editors: Hyo Sun Jung, Marc A. Rosen and Lili-Ann Wolff

Received: 22 June 2021

Accepted: 11 September 2021

Published: 15 September 2021

Publisher's Note: MDPI stays neutral with regard to jurisdictional claims in published maps and institutional affiliations.

Copyright: (c) 2021 by the authors. Licensee MDPI, Basel, Switzerland. This article is an open access article distributed under the terms and conditions of the Creative Commons Attribution (CC BY) license (https:// creativecommons.org/licenses/by/ $4.0 /)$.

\begin{abstract}
The main idea of this investigation is to identify a series of challenges and opportunities presented by telecommuting within the school system as a result of the SARS-Cov-2 pandemic. The objective of the paper is to identify key elements which are able to provide concrete assistance in building a sustainable online education system, with particular reference to Romania, as a system that can be used beyond the timeframe of the current pandemic. The methodology used for our scientific investigation is quantitative, based on an eight-item data collection instrument/questionnaire with 459 respondents (bachelor, masters, doctoral, and postdoctoral students-which makes this research a study from the perspective of the students' perceptions) with ages ranging from 18 to 53. In terms of results, the eight items were evaluated on a Likert Scale from 1 to 5 , leading to the formulation of seven hypotheses ( $\mathrm{H} 1$ to $\mathrm{H} 6)$, of which six were accepted and one was rejected (H7) (the questionnaire has a margin error/confidence interval of $\pm 4.5 \%$ and a confidence level of $\mathrm{P}=95 \%$ ). We concluded from the six validated hypotheses, coupled with the one which was invalidated, that telecommuting to online education was not only successful but also garnered a system characterized by sustainability. Despite the swiftness of telecommuting to online education and the perceptions of the student population, online learning can be efficient and sustainable, in which case further government policies can only improve a system that has already been proven to work.
\end{abstract}

Keywords: education; online; SARS-Cov-2; telecommuting; challenges and opportunities for sustainable education; teacher training in sustainable education; teaching resources for education for sustainability; virtual learning environments for sustainable education

\section{Introduction}

This paper is an attempt to understand the challenges and limitations of online education. To achieve this goal, the authors focused on the students' perspective and perceptions having realized that some concrete educational situations have changed and the degree of receptivity regarding these situations has waned. The SARS-Cov-2 pandemic forced specialists and practitioners-and it did so globally-not only to actively focus on research in the field of education but also to address the fact that some people/institutions involved in education were caught unprepared for online teaching. Concretely, a number of people and institutions had to quickly adapt to the COVID-19 circumstances, especially those with no prior expertise in online teaching. With this in mind, this study reveals the need for sustained research in the realm of online education irrespective of its level of complexity or the people/institutions in charge of educational policies and implementation. At the same 
time, the article aims at the actual improvement of didactic and pedagogical performances of teachers and professors across the spectrum of educational institutions with the specific purpose of limiting the shortcomings of online education as much as possible. It must be stated here that this article refers mainly to persons and institutions that had practiced traditional, face-to-face learning, or onsite education, and had to rapidly adapt to the new online challenges of internet-based learning because of COVID19 restrictions.

The purpose of the article is to identify elements that can assist in building a sustainable online education system in Romania, namely a system whose viability exceeds the temporal limits of the current SARS-Cov-2 pandemic and aims beyond it at concrete and long-lasting educational results with beneficial consequences on students and professors. In other words, this study seeks to identify concrete educational realities (by means of investigating seven distinct working hypotheses dealing with: 1 . fatigue, 2 . lack of human interaction, 3. poor internet connection, 4. lack of electronic devices, 5. lack of digital proficiency with reference to the teaching staff, 6. proper instruction, and 7. lack of conditions of participation in class time-all correlated to the clarity of duties). These seven hypotheses have concrete repercussions on educational actors (teachers and students alike); consequently, they were addressed in such a way that educational and learning competencies could be promoted while the education system could be enabled towards sustainable development. Having noticed that people responded in specific ways to the SARS-Cov-2 pandemic [1,2], we investigate how students and educators reacted to the reality of online teaching implemented in response to the SARS-Cov-2 pandemic, but we did so from the perspective of the students (the questionnaire focuses on student perceptions).

Since this article is an attempt to investigate the challenges and opportunities that traditional, onsite, and face-to-face institutions face in commuting to online education, the set of research questions that lay at the foundation of this research is listed below: (1) What level of fatigue did education professionals experience following the enforcement of online activities? (2) Is the lack of human interaction (poor internet connection/the lack of electronic devices/the lack of digital proficiency/the lack of conditions of participation in class time) a key aspect of professional dissatisfaction? (3) Are professional duties sufficiently clear for educational practitioners to perform adequately? (4) Was proper instruction provided to educational practitioners prior to commuting to online learning?

The structure of this paper includes the following sections: (1) Introduction (2) Literature Review (with a presentation of the purpose and objectives of the study within the contexts of specialized literature); (3) Research Hypotheses and Methods (with a description of research elements and the working hypotheses, coupled with the research method and the participants in the study); (4) The Research Results, which is followed by a section on (5) Discussions and (6) Conclusions.

\section{Literature Review}

The specialty literature regarding telecommuting in the university context in correlation with the effects of the SARS-Cov-2 pandemic arose relatively recently, and specialized articles on this problem have begun to be published simultaneously with the installation of online teaching at the global level, that is, beginning in 2020. As a result, the selection of articles reviewed in the present research is limited to publications beginning in the earlier mentioned period to the present day.

It should be highlighted here that Eastern Europe benefited from a crucial study of the motivation of university teaching personnel during the SARS-Cov-2 pandemic [3]. The research that lays at the foundation of this study was conducted on 202 teaching specialists from various Polish universities; in short, it revealed that the motivation of the persons involved in tertiary education teaching was significantly reduced during online activities. Aiming at a concrete solution, the authors suggest that focusing on students for satisfactory educational results is not sufficient; thus, a refocus on the teaching personnel and their needs during the implementation of their specific activities emerges as mandatory. In this sense, the contribution of this research to science is not only the result but also the 
way the result is achieved, having traced the reality of online educational challenges from the perceptions of those involved in educational activities. In recent times, especially in Romania, research attempts have been made to investigate the issue of the challenges generated by telecommuting in education, and one of the most fundamental studies in this respect was produced is Ref. [4], which—unlike this study-focuses on the professors' perspective, not on the students' perspective.

The reactions of certain researchers from China, the first nation affected by the pandemic and the country considered to be the original point from which the SARS-Cov-2 virus spread, were quite evident. Thus, there is a notable study edited by the authors of [5] in which a questionnaire was distributed among 39,854 students from the Chinese Southeast University, as a result of which they concluded that students did not find the reduplication of traditional teaching methods by online teaching to be neither viable and feasible, nor efficient and sustainable, the most challenging aspects raised by the students having to do with the adaptation of course or seminar materials for online platforms, the feedback concerning the completion of homework, evaluations, and control over the pace of learning.

Other Chinese researchers [6] note the fact that educational telecommuting in the university context is limited in many cases to the copying of didactic content and material from a physical format to an online format, without a prior adaptation on the part of chaired professors. The author of [7] also suggests that this problem can also translate into the inability of students to become autodidacts in the online teaching system most likely because it lacks efficiency given that neither teachers nor students seem to perceive it as sustainable in the long(er) run.

Furthermore, the authors of [8] underline the fact that there must be a clear differentiation between online teaching methods for distance learning, which has been in place in many universities for some time now, especially for certain specialties at the bachelor, master, and doctoral levels, on the one hand, and, on the other hand, the method of online teaching imposed by the state of emergency required by the SARS-Cov-2 pandemic nearly everywhere and for all specializations, irrespective of the level of study. They admit that online education, in the absence of studies demonstrating the contrary, carries the stigma of qualitatively weaker standards than in-person education, which reportedly renders it non-sustainable and inefficient.

The same differentiation between distance learning and online education is brought to light by the author of [9], who emphasizes the fact that training of academic staff for telecommuting is in strict concordance with the training in the domain of information technology, an idea also maintained in Ref. [10].

In this remark, the article [11] is remarkable. By means of a model having to do with telecollaboration in pedagogy (acronym FIT), it demonstrates that this form of telecommuting has a positive impact on the training of professors and has the potential to be an accepted and innovative method in pedagogy. Another research [9] even puts forth a profile of the digital, online professor for the future of education, through the application of its focus-group method to certain education experts from six different countries, suggesting that there is a great difference between the expectations of training on the part of a professor in traditional education and those exigencies imposed by online education, concluding in a totally new way that it is possible for the "human" professors of the future to be replaced by "robotic" ones. Whether the possible robotization of online pedagogy becomes a reality remains to be seen, although the positive take on online education brought to the fore by these two studies leaves more room for optimism regarding the sustainability and efficiency of online education.

This idea is taken up also by the authors of [12] by means of a questionnaire addressed to professors from the system of higher education in India, these being divided into two sets: those who adopted virtual classes as a means of teaching and those who did not. It was found that the lack of interaction in class, the difficulty of achieving understanding between professors and students as a result of internet connectivity problems, and the lack 
of qualified personnel can constitute important liabilities of the system of higher education, in the quick transition toward a system of online teaching.

A similar study [13] among a number of professors belonging to the higher education system of Israel indicates the fact that a success factor in the adoption of virtual teaching methods is constituted by the institutionalization, by means of the relevant ministry, of certain dedicated centers for the professionalization of human resources in the university context for the adaptation to telecommuting. Other authors [14] even sketch the contours of a four-phase model for adapting traditional teaching to online, concluding that the use of technology without physical interaction can generate problems of synchronization between the expectations of professors and those of students having to do with the results of learning.

Challenging as they are, these problems also contain an inherent reality which is, at least in theory, the very core of sustainability of online education: students were indeed brought together in a virtual class and interaction with them was possible. How efficient this interaction was or is to this moment is a different aspect and remains to be clarified but the very existence of virtual online classes is a sign that the sustainability of online education is not impossible to achieve.

As further support for this thesis, one can point to the study effected by the authors of [15], which addressed a questionnaire to a number of university students from the United States having to do with their perception of their courses as transitioned from traditional to online education. For the most part, the opinions of the students questioned were negative, invoking the fact that telecommuting in the university system brings about a lack of interest, of interaction, of availability on their part, and even anxiety about the use of the computer or other mobile devices. This idea is maintained also in Ref. [16] as a result of a questionnaire addressed to students from the higher education system of Indonesia, as well as in Ref. [17], which applied a relational screening model to students from different state universities in Turkey. There is also a transition from online learning to online evaluating, which becomes much more problematic. It has also been suggested [18] that the evaluation practices of online students are not adapted to the specificities of telecommuting such as they were imposed by the situation of emergency brought about by the SARS-Cov-2 pandemic.

In agreement with these findings, it is possible to conclude [19] on the basis of a questionnaire addressed to students from Georgia that it is impossible to nuance a preliminary idea, whether positive or negative, with respect to the system of evaluation of courses taught online during the pandemic insofar as it would require a minute comparison with the results of the generations of students of the same disciplines from before, when teaching was undertaken in a traditional way, in the classroom. Ref. [20] indicates that students cannot be checked for cheating on online examinations, a fact that raises serious questions about the evaluability of students in telecommuting in higher education.

Some specialists [21] mention that the same problem can constitute a "breach of security" for the practice of telecommuting applied to the university context, which will produce not only short-term but also long-term effects, in the context of the pandemic as also in the long run, in the post-pandemic context. A more recent study [22] reveals that the tendency on the part of the universities is to tolerate cheating on online exams precisely because the means for fighting this phenomenon are not available.

It should be stated here that these challenges-inherent not only to online education but also to its traditional onsite counterpart-bear no direct influence on the sustainability of online education. The fact that certain aspects of education (such as fair evaluation) cannot be addressed is not an indicator that online education per se lacks sustainability. It can have challenges in the efficiency department, but proper methodologies can remedy such situations if 'out-of-the-box' thinking is applied to traditional pedagogical perceptions and methods.

For other researchers, such as [23,24], telecommuting becomes a much more acute problem for higher education in the medical and technical domains, as well as for the 
more vocational wings. On the other hand, if one analyzes the opportunities generated by the adoption of telecommuting in the higher educational system, one can generalize, in keeping with the proposal of [25], that online education is favorable to students with limited possibilities of time, money, and transport. In this particular case, challenges are-and should be treated as-opportunities to reach students who would otherwise have difficulties in benefiting from educational services. Such a practice would most certainly turn online education into a sustainable field of expertise.

It has been claimed [14] that online education ought not to be seen as a solution to all the challenges generated by telecommuting in the university system, and that, much the same as in any other context, the practice offered by the coming years of the pandemic context can lead to the perfecting of practices in this domain. One may [26] even bring to light the fact that a method of online teaching has to be accepted from the very beginning as involving both synchronous and asynchronous aspects.

An exploratory study based on an interview with a panel of experts from universities in Canada, Switzerland, Spain, and Australia $[27,28]$ highlights the fact that accessibility and autonomy are, for students, the success factor in the experience with the online teaching system.

On the same note, but on the basis of an exploratory study founded upon an interview with a panel of experts from universities in America, the authors of [29] emphasize that adapting the higher education system to telecommuting presupposes the assumption of multiple roles on the part of the professor facilitator, course designer, content manager, a debate expert on certain topics and, last but not least, the role of mentor. If so, sustainability is an inherent feature of online education given the multiple roles assumed by a single person, namely the teaching professional.

A number of authors [30] approach pandemic pedagogy from a certain politicaleconomic bent, stating that it has generated, for students as also for professors, certain new business opportunities, for acquiring software solutions (online platforms for universities) and hardware solutions (communications systems), favoring the appearance of start-up firms in the domain of EdTech [31]. All these notwithstanding, there have been and continue to be zones with limited access to information technologies, such as rural zones in South Africa [32], the Philippines [33], and also in other countries from Asia, such as South Korea, Russia, Saudi Arabia, China, India, Japan, as well as in Africa, such as Algeria, Egypt, Ghana, Kenya, Namibia, and Uganda [34,35]. All these, however difficult with their challenges to learning, remain a large spectrum of opportunities for online education with a reasonably cautious prospect of efficiency and sustainability.

\section{Research Hypotheses and Methods}

The inquiry range is representative of the student population investigated in this study with a confidence interval of $\pm 4.5 \%$, within a confidence level of $p=95 \%$. The total number of students that provided feedback via the questionnaire is 459 , according to Table 1 .

Table 1. Research Data Sheet.

\begin{tabular}{ll}
\hline Study Universe & 500,000 Students \\
\hline Data Collection Method & $\begin{array}{l}\text { Structured questionnaire distributed to } \\
\text { students via internet }\end{array}$ \\
\hline Sample Unit & $\begin{array}{l}\text { Students in all forms of education (Bachelor, } \\
\text { Master, Doctorate, Postdoctorate) }\end{array}$ \\
\hline Sample & 459 \\
\hline Margin of Error (Confidence Interval) & $\pm 4.5 \%$ \\
\hline Confidence Level & $p=95 \%$ \\
\hline
\end{tabular}

The working hypotheses were formulated in connection with educational concepts and their correlation both negatively and positively. Seven hypotheses were subject to 
validation or invalidation. All seven hypotheses focus on whether online education and its corresponding consequences are eventually and essentially dependent on one's comprehension of specific educational tasks and the content of educational materials (what we called 'clarity of duties'). Thus, the inquiry aimed at fatigue, the lack of human interaction, the poor internet connection, the lack of electronic devices, the lack of digital competencies on the part of professors, instruction and class participation, as well as how these are correlated (or not) with the clarity of duties which students have to accomplish.

The research method is based on a questionnaire with open and closed questions that were dealt with in connection with the Likert scale [36]. The questionnaire was divided into four sections which included 36 questions. The total number of participants was 459 (bachelor, master, and doctoral students, as well as postdoctoral researchers) from state and private universities across Romania. The respondents came from both urban and rural areas.

Hypothesis 1 (H1). The challenge of fatigue is negatively correlated with the opportunity presented by the clarity of duties.

As a professional and social reality, telecommuting is not novel, neither at the global level nor in Romania, insofar as interpersonal interactions facilitated by specialized teleconferencing platforms have been possible especially after 2007 (Lynk), 2011 (Zoom), 2013 (Skype for Business), and 2017 (Microsoft Teams). At the same time, as a result of the conditions caused by the SARS-COV-2 pandemic, the work undertaken on the internet by means of such platforms has intensified, especially on the basis of governmental measures regarding physical distancing alongside imposing a national state of emergency in countries more or less affected by the recent medical situation. In Romania, governmental order no. 195 from 16 March 2020 establishing a state of emergency in the country necessitated a reconsideration of the pursuit of professional activities in every domain of work, from the educational and medical systems to economic activities undertaken by the various firms implicated in production or service and indeed any other aspect which presupposed the possibility of accomplishing its task by means of the internet.

A year after restrictions were imposed on collective activities for the sake of more effectively dealing with the effects of the spread of SARS-Cov-2, one can observe certain challenging aspects with repercussions for all domains of activity, even granting that some are more visible in certain professional domains, making themselves more intensely felt as a result of the natures of certain activities or of the general profiles of certain people. For example, as a result of some persons having spent a significant number of hours in front of an electronic device (computer, tablet, telephone, etc.), there have appeared, relatively rapidly, cases of personal (or even interpersonal) fatigue and professional inefficiency, which presents a serious challenge to the sustainability of the education process. Such situations, which are more noticeable in the domain of education, have affected to a greater or lesser degree all persons involved in the educational process, thus professors and teachers as well as students of varying ages [37]. Consequently, facilitating interpersonal interactions through the medium of the internet, thus by means of certain devices, has led, on the one hand, to the possibility of communication between the agents involved, but also, on the other, to the exacerbation of certain problems which would otherwise be easily managed, namely fatigue and boredom [38]. Other domains of work have also been affected by this same challenge of fatigue and boredom in contexts of human interaction and interpersonal communication having suffered not only because of the mediation offered by certain specialized devices but also because of the unfamiliar character of this mode of mediation, people sensing something unnatural in the virtual model of presence of others.

Nevertheless, if fatigue is a major challenge to online education, then the proper adjustment of duties (such as the reconsideration of the teaching methods, the class content, and the number of hours spent on teaching) can be a key opportunity for the actual building of sustainable online education. 
Hypothesis 2 (H2). The challenge of lack of human interaction is negatively correlated with the opportunity presented by the clarity of duties.

Consequently, one of the problematic - and in this sense most important-challenges of sustainable telecommuting is the lack of interpersonal communion, which presupposes the physical presence and proximity made possible by working in the same room or else general context of a shared workplace. Online-mediated communication and interaction appear not to be sufficient to secure that fatigue, inefficiency, and stress be reduced together with the growth of the parameters of productivity of work. It seems that all domains of activity, but especially education, suffered as a result of the lack of interpersonal communion caused by the physical distancing imposed among people working.

As to why the lack of interpersonal communion occurs as a result of physical distancing, one possible answer resides in the fact that interpersonal interaction is a social reality dependent on key mutually prosocial behavior characterized by generosity and trust [39]. In the absence of such social parameters, interpersonal relations are likely to diminish and suffer damage of some sort in the context of telecommuting from onsite teaching to online education.

However, if the lack of human interaction is currently perceived as a challenge for online education, the opportunity to correct the situation is present in the redrafting of teaching duties by taking into account the fact that the lack of human interaction may be supplemented by adequate online interaction translated as work engagement. In the long run, the clearer the teaching duties, the greater the chance that the lack of human interaction should be turned into a sustainable opportunity for online teaching through work engagement which—as highlighted by [4] — is 'a prerequisite for the longterm sustainability of any education system'.

Hypothesis 3 (H3). The challenge of poor internet connection is negatively correlated with the opportunity presented by the clarity of duties.

Another challenge that has appeared as a result of the imposition of sustainable telecommuting as a result of the SARS-Cov-2 pandemic is the inadequacy of specialized devices. Whether it is a matter of computers, tablets, cellular phones, or whatever else, these have often proven to be inefficient insofar as not all persons involved in professional activities are in possession of the latest versions of these devices such as to facilitate an online connection within normal parameters.

As a result, problems having to do with internet connection have appeared, which lead to the interruption of communications among persons involved in professional activities and which produce undesired effects on the work process. Especially notable in the sphere of education, these challenges have afflicted not only the urban context, where the standard of living would permit the obtaining of more efficient devices but also in rural zones, where the absence of such devices has led to the cessation of didactic activity for longer periods of time [37].

The challenge of poor internet connectivity is an objective reality that cannot be dealt with exclusively by education professionals. In order for online education to become sustainable during the time of the pandemic, firm government intervention is needed so that online connectivity becomes a reality throughout all geographic regions, not an exception limited to urban centers. If sustained government intervention is not implemented promptly, the challenge of poor internet connection is likely to widen the divide between rural and urban centers which may result in inequalities of access to online education, potentially similar to those extant in Central and Eastern Europe before and immediately after the fall of Communism [40].

Hypothesis 4 (H4). The challenge of lack of electronic devices is negatively correlated with the opportunity presented by the clarity of duties. 
Therefore, the inadequacy or even absence of electronic devices was and is an extremely important problem which must be taken into consideration in the matter of evaluating the efficiency and sustainability of professional activities not only in education but in any field of work insofar as the possibility of communication among the parties involved in some work is seriously affected in the long term. Online work presents counterproductive potential as a result of numerous stress-inducing factors generated by the mediation offered by electronic devices, and the absence or technological inadequacy of these automatically leads not only to negative effects for professional activities but even possibly to their total interruption.

Moreover, the lack of electronic devices results in having privileged students and underprivileged students which, in turn, may affect the kind and type of education they pursue in the future. For instance, while privileged students usually enroll in Law and Medicine, underprivileged ones tend to prefer Engineering, as well as Arts and Sciences [41] (p. 157). In other words, the lack of electronic devices is not only a matter of educational efficiency in the short term but also a key aspect of educational steering and professional accomplishment in the long term.

The fact that electronic devices are either lacking or inadequate to support online education is nonetheless another objective challenge for online education during this particular pandemic. The Romanian government is therefore presented with the opportunity to update and upgrade the national education system with electronic devices that are capable of sustaining online education not only during this pandemic but also beyond its timeframe.

Hypothesis 5 (H5). The challenge of the absence of digital competencies on the part of professors is correlated with the opportunity presented by the clarity of duties.

At the same time, the possession of electronic devices of the latest generation does not guarantee the efficiency and sustainability of professional activities undertaken online. In order for these to function in normal conditions, there is a need for at least two additional, essential factors whose co-occurrence is not always guaranteed: first, internet service providers need to be operating at an optimal level in order for sufficiently large data transfers to take place for the sake of communication; second, specialized communications platforms (such as Skype or Zoom) must be operating efficiently for long periods of time. Professional activities are seriously affected by the absence of either of these two factors, a fact that is evident in every domain of activity, but especially in education [37]. Internet services decline in quality correlatively with the growth of the distance between urban and rural locales, even to the extent that not only in Romania but even globally, there are rural areas where no internet service is available at all. On the other hand, even in areas where internet service is optimal, there can be no avoiding the problems caused by the malfunctioning or suspension of online platforms, oftentimes caused by overcrowding at certain moments.

Concretely speaking, the educational system in Romania is confronted with an information-trafficking problem from the early hours of the morning, when the specialized teleconferencing platforms are affected by the massive online presence of users from the United States of America (8:00 AM in Romania falls in line with 2:00 AM in the US). This situation remains pressing in light of the extension of restrictive measures imposed at the global level as well as the increase in the number of users. As a result, the efficiency and sustainability of telecommuting depend on a cumulation of factors, in which the personal and subjective ones seem significantly fewer than the technological, objective ones, the physical-material nature of which have a negative impact on professional activities. A secure internet connection guaranteed by the service provider is essential for efficient and sustainable telecommuting and especially online education [42].

The problem of telecommuting remains extremely complex insofar as the efficiency of activities undertaken through the mediation of the internet is not guaranteed by the availability of excellent internet service, or of the latest electronic devices and online 
platforms whose normal functioning is guaranteed. On the contrary, even in the case in which all these conditions are fulfilled, professional activities in all domains, as also in education, continue to be affected by problems caused by factors of a personal nature. For example, inadequate familiarity with online devices (and, implicitly, with the specialized platforms) on the part of some persons involved in professional activities (employees and employers, students and educators) will affect labor and its specific activities in a way that can be considered negative. Education seems especially vulnerable in this respect, insofar as educators typically have not been professionally trained in such a way as to possess the requisite digital competencies [37]. Even if this specific digital competency could be assured for them by means of a certificate, the variety of online devices and specialized platforms does not guarantee a significant level of competency and familiarity with all the devices and platforms currently on the market.

However, this only represents half of the problem and its corresponding challenge for online education. Even in the case in which educators might be specialized in the digital domain in such a way as to guarantee a high level of professional competency in the use of devices and online platforms, students at all levels of education constitute an extremely diverse social category who do not all possess the requisite digital competencies. If, in general, it is believed that younger students from the urban sector, both in primary and secondary education as well as at the university level, might be more competent such as to be capable of learning through online educational services, there would remain the problem of those students from rural areas who are not so competent. The situation is in fact much more complex, given that students of all levels from both rural and urban areas are affected by a lack of familiarity with devices and online platforms.

In this same context, the manner in which devices and online platforms are used may positively or negatively influence professional activities, including those in the educational sphere. For example, in the case in which students and even educators are recommended to mute their video cameras for the sake of limiting data transfer and facilitating verbal communication, the efficiency of the didactic process can drop dramatically. The absence of personal interaction in all its complexity, such as the invisibility of the face or at least of the eyes of an interlocutor, are two challenges that seriously affect interpersonal communication in students of all levels and ages, especially those in primary education which, again, reduces the efficiency and sustainability of online education. For this reason, the possibility of the unmediated guidance of students at all levels through direct pedagogical action is significantly reduced with negative consequences for the educational process from the point of view of both the educator (who no longer has the possibility of guiding his or her students in a normal manner) as well as of the student (who no longer benefits from the entire didactic experience of the educator).

Nevertheless, this particular challenge can be addressed in a sustainable manner by a thorough adaptation of teacher-student interaction along the lines of new 'out-of-the-box' pedagogical methods. Rethinking digital competencies as mandatory pedagogical means to achieve a sustainable online education program, and not as optional personal abilities, may be a way forward towards efficiency and sustainability in online education.

Hypothesis 6 (H6). The challenge of instruction is correlated with the opportunity presented by the clarity of duties.

The impossibility of realizing effective communication between the persons involved in professional activities (employers-employees, educators-students) leads often to professional abandonment, a sign that efficiency and sustainability are not characteristics of a certain professional field. This phenomenon, which is especially noticeable in the educational system, has direct and complex repercussions, normally with respect to a single category: students. Leaving to the side situations caused by professional and scientific incompetence on the part of educators who undertake their teaching activities by means of reading off information with supplementary explanations, abandonment remains a problem in education insofar as students do not manage to perceive the validity and efficiency 
of their professional activity. The incapacity to understand the materials they are taught, the lack of effective communication with educators, the lack of interaction with their fellow students, as well as the impossibility of establishing a term for the reestablishment of prior conditions (from before the SARS-Cov-2 pandemic) are just a few aspects leading to the phenomenon of abandonment [37].

Abandonment is an extremely complex reality brought about as a result of an accumulation of factors. For example, in a study realized by the Romanian Council for Students [37] at the beginning of the 2020-2021 school year, it was observed that the Romanian educational system suffers from at least five factors in its specific professional activities that are perceived negatively by students: the digital competencies of its educators; the uninterest of its educators; the lack of e-learning platforms; the lack of internet connection; and the lack of electronic devices. The order in which they are here presented is also the order of their respective gravity, so that $50 \%$ of respondents identified the lack of digital competencies on the part of their educators as being the gravest problem, the rest constituting a perceptibly smaller percentage of cases.

Whether one speaks of the educators or of the students, however, professional abandonment is preceded by a lack of motivation which affects the entire educational system, as also other domains of activity dependent upon telecommuting. In the same report of the Romanian Council for Students [37], one observes that $40.8 \%$ of students desire exclusively in-person courses, whereas only $15.4 \%$ are considering exclusively online courses. No fewer than $30.4 \%$ are in agreement with the hybrid system organized according to discipline, whereas $11.5 \%$ would prefer a hybrid system organized according to groups. It is obvious, however, that physical presence in school—which can be extrapolated into any professional context-is extremely important and is reflected in the choices of most students who desire to be physically present at school irrespective of the adoption of an exclusively physical or hybrid system [37].

Apart from physical presence, telecommuting can become stressful insofar as it generates, beyond the efficiency of the transmission of information through online systems, a lack of motivation, the origin of which seems to be the impossibility of interaction with a community and the lack of meaningfulness that follows from this. Human communion, the simple physical presence in proximity of other persons in the same professional and educational context, seems to be a determining factor for efficiency and growing personal motivation in the pursuit of professional activities, one which telecommuting cannot provide.

This matter of professional abandonment, which was previously mentioned, considered also in the educational context, necessarily introduces into the discussion the relationship between employer and employee, as well as that between the educator and the student. Whereas misunderstandings in the relationship between the employer and employee can be resolved through direct discussions, the situation between the educator and the student (who is in most cases a minor) is more complicated. In the first place, one cannot speak of a real relationship between educator and student in the context of telecommuting. Or, at the least, not of one which could cover the affective needs of the latter, given that the proximity provided by the internet reflects an obvious geographical distance.

Moreover, if video services are muted for the sake of purely audio conversations precisely so that information can be transmitted, one of the fundamental problems of education from the perspective of the student is precisely the impossibility of nonverbally interacting with the educator, a problem which possesses validity for the educator as well who cannot see and evaluate in real-time the reactions of the student [37]. From a didactic point of view, the reality of telecommuting in the educational domain calls into question the very methodology of work, or more precisely the methodology of teaching. If teaching was done in a certain manner in the conditions from before the SARS-Cov-2 pandemic, now the situation is more complex, so that the methods of teaching need (probably if not quite almost certainly) changing or at least adapting to the new situation. 
The transmission of information cannot remain the only or even the most important component of teaching. In order for online education to be both efficient and sustainable, the educator must know how each student functions according to his or her age, preoccupations, and aptitudes in order to be sure that as large a number as possible of students manage to assimilate the material, or at least to understand it, given the conditions in which the communication between the educator and student is lacking in non-verbal aspects, whose essential character becomes all the more evident in the absence of physical proximity. The challenge of (bad) instruction is currently one of the most important opportunities which arise within the field of education, especially when online education is mandatory because of pandemic-related restrictions. However, good instruction-the very foundation of sustainable online education-is anchored in both personal development and government legislation, two aspects that are unlikely to work together within a short timeframe, such as that caused by the pandemic.

Hypothesis 7 (H7). The challenge of lack of conditions for participation in class time is negatively correlated with the opportunity presented by the clarity of duties.

In this context, however, it becomes evidently necessary that educators be trained for the sake of efficient as well as sustainable educational telecommuting. Therefore, it will be necessary to conceive and produce certain methodological guides having to do at least with the fundamental aspects of online education so that the telecommuting work of educators not limit itself only to the parameters realized by the transmitter, but also those of the receiver, that is, of the student who needs not only to receive information but also to understand, being able later to utilize it in a theoretical and even practical manner [37]. Such aspects, which meet the needs of teachers and students, are instrumental for the efficient implementation of sustainable online education.

Educational telecommuting, or online schooling as it was called from the beginning of the SARS-Cov-2 pandemic, has the great advantage of securing the presence during class times of all those with an internet connection, electronic devices, and specialized software, while in urban areas it is possible that these should occur in an encouraging proportion. Things are not the same in rural areas, where it may be impossible for students to benefit from the three essential aspects just mentioned. So, as it stands right now, sustainability in online education is objectively dependent on the geographical location and the political-administrative configuration of the country's regions.

Consequently, however useful they may be, and they are, methodological guides accomplish nothing other than to make evident, beyond the positive factors of educational telecommuting, the great inadequacies of the educational system, not only in the context of the present pandemic but also in the more familiar situation of the Romanian educational system in the absence of the present medical conditions. Sustainability, therefore, is a matter of complex personal and government involvement to the point that methodological guides are genuinely implemented for the sake of efficient online education which benefits not only the students but also the teachers.

The report put forth by the Romanian Council for Students [37] makes evident not only the inadequacy of the majority of educators vis-à-vis the digital competencies necessary for educational telecommuting, but also certain aspects that are probably impossible to realize in a short amount of time [43]. For the vast majority, students at the primary and secondary levels desire a noticeable increase of digital competencies on the part of educators, who might stand to benefit from the offer of further training in this respect so that online education becomes truly sustainable.

In other words, each educator, irrespective of age, preference, and conviction in the matter of educational activity, ought to be capable of working online, ought to know how the internet works, as well as the devices that make the access to virtual reality possible [44]. Also, educators should in equal measure be conscious not only of the different modalities of online teaching, but also of the manner in which students learn in conditions of educational telecommuting, what learning strategies these adopt, and how the objectives not only of 
teaching but also of learning might be reached. Awareness with respect to teaching and learning is foundational for building a sustainable program of efficient online education.

Thus, the digital training of all educators ought to be obligatory, not only in present pandemic conditions but also after the return to normalcy, insofar as virtual reality has been for some time an inexhaustible and inevitable store of resources for teaching and learning. In other words, educational telecommuting will probably become an important if not quite essential aspect of post-pandemic educational activity intended to assist not only the teaching process but also that of learning. Teaching methods and learning strategies-both adapted to online pedagogy - cannot be excluded if online education is to be sustainable during the pandemic and likely beyond its time frame.

The same report also enumerates certain concrete actions which the government of Romania ought to take by means of the Minister of Education so that online education becomes efficient and sustainable. First, classrooms must be equipped with apparatuses to make educational telecommuting possible, not only in present conditions of the pandemic but also after these have passed, whatever the form might be in which physical presence at schools will be accepted [43] — which is to say that infrastructure is a problem that needs rapid resolution. Second, the development of e-learning platforms is vital in this context, all the more so because such platforms would assure a common denominator for the entire Romanian educational system, not only through its functions but also through its content [43]. Connectivity, thus, is a problem that requires special attention on the part of governmental authorities [42]. One of the important aspects of these e-learning platforms would be the possibility of teaching both online and offline, that is, the possibility of both synchronous and asynchronous learning, which would offer diverse possibilities of learning so that the greatest possible number of students could adapt their learning strategies to a varied range of teaching possibilities. Third, once the equipping of classrooms with an adequate apparatus and the development of e-learning platforms is accomplished, it will be necessary to establish certain quality standards for educational telecommuting, given that students request the monitorization of didactic activities on the part of the Minister of Education, an aspect which remains questionable from the point of view of its realization [43]. Fourth and finally, there ought to exist a variety of plausible and implementable scenarios having to do with the realization of courses according to different possible situations brought about by the pandemic: for example, physical presence, virtual or mixed, which should nevertheless offer an increased efficiency of all aspects pertaining to educational telecommuting from the points of view of both the educator and the student [43].

In the absence of such measures at the level of the government, educational telecommuting could lead to a chaotic situation in the educational system, both at the preuniversity and university levels which results in inefficiency and lack of sustainability. For example, in the university educational system, even after the imposition of restrictions that led to the necessity of online teaching, not a few educators refused to teach online, preferring to make up for lost time during the summer vacation period. Others increased the volume of homework in order to supplement the lack of physical presence in the classroom, without however offering further pedagogical support in this respect [38].

As a result of isolation measures, often at home with their parents, some university students ended up in the situation of no longer being able to assimilate the course materials, being extremely negatively affected from a psychological point of view. Medical and technical schools found themselves obligated to cease laboratory operations, which are otherwise vital for their related specialties. In these conditions, students found themselves unable to perform certain essential activities, leading to consequences that are impossible to quantify in this situation. The preuniversity educational system was equally negatively affected because some educators renounced the in-person schedule out of a preference for operating online or announcing homework at other times than those mentioned in the class schedule. Once schools telecommuted to online teaching because of the SARS-Cov-2 pandemic, parental involvement and became essential especially for smaller children, which resulted in additional stress on all parties involved. Parental support is important for 
education [45] (p. 291) but it seems incapable of supplementing, let alone replacing, the professional training of specialized teachers.

Likewise, some educators did not transition to online at all, so educational telecommuting did not take place in their cases. Subject matters such as foreign languages and religion were not taught at all, the only topics which were taught being those that are part of the bachelor's curriculum. In this case, however, the challenge was not only the absence of the educators but also the evaluation of knowledge gained in such situations [42]. Neither of the two situations presented above appears to have been addressed, let alone turned into opportunities to move in the direction of sustainable online education. This is why government intervention is mandatory in such situations, especially if one takes into account the fact that religion and religiosity result in philanthropic behavior which, in turn, includes the willingness to provide aid [46], a key ingredient in the new teaching experience of online education.

One of the greatest challenges confronting students of all levels during the pandemic was the increased volume of homework required by educators as a supplement for the lack of physical presence in the classroom. In this case, educational telecommuting became a means for exploiting students beyond the limits imposed by the accepted curriculum, the students not only being obligated to work more than normal, but also to manage their tasks entirely on their own, apart from any concrete pedagogical support which ought to have been offered by the educators. Pseudo-compensation for the lack of face-to-face interaction can destroy sustainable efforts to make online education sustainable; this is why adaptation and reasonability should be key parameters in the process of building not only efficiency but also sustainability within Romania's online education.

Moreover, in the case of educators who lacked the requisite digital competencies necessary for realizing average-level didactic activities by means of educational telecommuting, the work of students not only grew quantitatively but also became a source of stress. For example, students at the technical colleges found themselves having to learn advanced mathematics, physics, and other subject matters, which normally would require constant explanation from the educator by means of examples and the retelling of complex formulae, a factor which is entirely absent in online education. So, in 2020 at least the limits of educational telecommuting became quite evident [38]. Such limits need to be transcended if sustainability is to genuinely become a feature of online education.

The lack of special practice created a situation in which students did not understand the materials and phenomena taught online, dialogs with their professors being in such circumstances extremely burdensome, not only because of the educators themselves and their given lack of digital competencies but also because of problems with internet connection and other strictly technical problems which affected interaction during class time. With such challenges still predominant across the country, Romania's online education is still to become both efficient and sustainable for a considerable number of people, regardless of whether they belong to the teaching or the learning population.

Nevertheless, the situation of students at the preuniversity level is more complex insofar as these are mostly minors whose affective needs are other than those of adults. Younger students complain about the chaotic program, schedules not being kept, pressure from the part of some educators in subject matters that in normal conditions would be far less stressful, the absence during class time of some educators, as well as the simple renunciation for long periods of time of certain subject matters and the lack of a constant connection with certain professors. In such conditions, the educational system is far from achieving a desirable level of efficiency, the students being bothered not only by the lack of interest on the part of their teachers but also by the inefficiency of the didactic act which itself brings about the inefficiency of learning, another objective fact revealing online education is yet to become sustainable in many of its key aspects.

There are reports of cases in which certain classes were not held at all by means of educational telecommuting so that an entire school went without online teaching, the students themselves being deprived of their right to education. The lack of organization evidenced 
in such situations reveals not only the failings of the system but also the inadequacy of the educators in matters of digital activities, an aspect that left a negative mark on the education offered during the year 2020, as much in the preuniversity system as also in the university system. From this perspective, the sustainability of Romania's online education is profoundly dependent on digital competence with respect to both teachers and students.

However, the negative effects of the educational situation brought about by the current pandemic are differently felt by those benefiting from online education, that is, by students at all levels. According to Rares Cârligeanu, an expert in education, those most affected seem to be students in the sixth and seventh grades who do not manage to form the requisite abilities for the mastery of certain fundamental pieces of knowledge that are essential for their later education [47]. In this context, the challenge has to do not only with the teaching of certain basic notions but also the verification of the stability of the knowledge gained by the students, which can no longer be realistically appraised. In such cases, the country's online education cannot become sustainable in the absence of proper assessment methodologies.

Yet it must be emphasized that the situation arisen as a result of the pandemic has negatively affected not only students but also educators, whose principal preoccupation was that of assuring equal access to education for all students [48]. Even granting that this preoccupation cannot be absolutized, it can probably be generalized or at least particularized in the case of educators who pushed themselves to undertake their online activities by means of telecommuting, and in so doing, they at least attempted to transform the current challenges into opportunities leading to efficiency and sustainability in Romania's online education. In the preuniversity system, some 650 instructors registered for an online course intended not only to improve their digital competencies, but also their perceptions of the needs of students in the light of the challenges raised by the use of the internet, the transformation of the current situation into a series of opportunities with positive potential, as well as of the relation between school, family, and community.

In other words, at least in certain social contexts, a need was identified for a solution to the challenges raised in the educational system as a result of the SARS-COV-2 pandemic, which would require the participation of as many people as can help. Thus, the principal agents involved in telecommuting are not only the students and their professors but also the family and the community as a whole [48]. At the same time, the manner in which the family and the community can be involved in building a sustainable online education in Romania is a challenge the theoretical discussion and quantification of which remains a problematic question without concrete answers at the present moment.

\section{Results}

The study was conducted in Romania, a country severely affected by the COVID-19 pandemic, where a large part of the economic activity was performed through teleworking [49]. The COVID-19 pandemic led to stress among employees, so they need to adapt to teleworking resulted in job instability and insecurity challenges [50], a fact that affected especially the field of education; the activity within educational institutions was done by teleworking, so professors and students had to adapt to online teaching.

This study is quantitative, and the instrument utilized for the collection of data is the online questionnaire addressed to university students at the bachelor, master, doctoral, and postdoctoral levels. The questionnaire was filled in by 436 student respondents (final 459), with ages ranging from 18 to 53 .

Of them, $59.2 \%$ were women and $40.8 \%$ were men. The items used in the questionnaire were proposed by the authors of this research based on patterns proposed by previous social sciences research [50]; thus, the single items were formulated and evaluated with a Likert Scale from 1 to 5 , where 1 is very unlikely and 5 is very likely (as indicated in Table 2). 
Table 2. Proposed items for the analyzed variables.

\begin{tabular}{ll}
\hline Variables & Proposed Items \\
\hline 1. Fatigue & $\begin{array}{l}\text { 1. How tired have you felt since online } \\
\text { activities were enforced formally? }\end{array}$ \\
\hline 2. Lack of human interaction & $\begin{array}{l}\text { 2. With reference to online learning, to what } \\
\text { degree are you displeased with the following } \\
\text { aspects? (Lack of human interaction) }\end{array}$ \\
\hline 3. Poor internet connection & $\begin{array}{l}\text { 3. With reference to online learning, to what } \\
\text { degree are you displeased with the following } \\
\text { aspects? (Poor internet connection) }\end{array}$ \\
\hline 4. Lack of electronic devices & $\begin{array}{l}\text { 4. With reference to online learning, to what } \\
\text { degree are you displeased with the following } \\
\text { aspects? (Lack of electronic devices) }\end{array}$ \\
\hline 5. Lack of digital proficiency with reference to & $\begin{array}{l}\text { 5. With reference to online learning, to what } \\
\text { degree are you displeased with the following } \\
\text { aspects? (Lack of digital proficiency with } \\
\text { reference to the teaching staff) }\end{array}$ \\
\hline 6. (Proper) Instruction & $\begin{array}{l}\text { 6. Did you benefit from proper instruction as } \\
\text { you began online learning? }\end{array}$ \\
\hline time & $\begin{array}{l}\text { 7. With reference to online learning, to what } \\
\text { degree are you displeased with the following } \\
\text { aspects? (Lack of conditions of participation in } \\
\text { class time) }\end{array}$ \\
\hline $\begin{array}{l}\text { 8. To what degree do you think the duties you } \\
\text { are supposed to fulfill are clear? }\end{array}$
\end{tabular}

The analysis of the data and the testing of the hypotheses were performed by means of the Correlation Analysis method in conjunction with the Spearman coefficient, through the use of SPSS21 (Table 3).

Table 3. Correlation analysis results. Spearman coefficient.

\begin{tabular}{|c|c|c|c|c|c|c|c|c|c|}
\hline & & Fatigue & $\begin{array}{c}\text { Lack of } \\
\text { Human } \\
\text { Interaction }\end{array}$ & $\begin{array}{c}\text { Poor } \\
\text { Internet } \\
\text { Connection }\end{array}$ & $\begin{array}{l}\text { Lack of } \\
\text { Electronic } \\
\text { Devices }\end{array}$ & $\begin{array}{l}\text { Lack of Digital } \\
\text { Proficiency with } \\
\text { Reference to the } \\
\text { Teaching Staff }\end{array}$ & $\begin{array}{c}\text { (Proper) } \\
\text { Instruction }\end{array}$ & $\begin{array}{c}\text { Lack of } \\
\text { Conditions } \\
\text { of Partici- } \\
\text { pation in } \\
\text { Class Time }\end{array}$ & $\begin{array}{c}\text { Clarity of } \\
\text { Duties }\end{array}$ \\
\hline \multirow[t]{2}{*}{ Fatigue } & $\begin{array}{l}\text { Correlation } \\
\text { Coefficient }\end{array}$ & 1.000 & $0.443^{* *}$ & $0.434 * *$ & $0.400 * *$ & $0.386^{* *}$ & $-0.303 * *$ & -0.065 & $-0.383^{* *}$ \\
\hline & $\begin{array}{c}\text { Sig. } \\
\text { (2-tailed) }\end{array}$ & . & 0.000 & 0.000 & 0.000 & 0.000 & 0.000 & 0.280 & 0.000 \\
\hline \multirow[t]{2}{*}{$\begin{array}{l}\text { Lack of } \\
\text { human } \\
\text { interaction }\end{array}$} & $\begin{array}{l}\text { Correlation } \\
\text { Coefficient }\end{array}$ & $0.443^{* *}$ & 1.000 & $0.358 * *$ & $0.378 * *$ & $0.453^{* *}$ & $-0.334^{* *}$ & -0.031 & $-0.287^{* *}$ \\
\hline & $\begin{array}{c}\text { Sig. } \\
\text { (2-tailed) }\end{array}$ & 0.000 & . & 0.000 & 0.000 & 0.000 & 0.000 & 0.604 & 0.000 \\
\hline \multirow[t]{2}{*}{$\begin{array}{l}\text { Poor internet } \\
\text { connection }\end{array}$} & $\begin{array}{l}\text { Correlation } \\
\text { Coefficient }\end{array}$ & $0.434 * *$ & $0.358^{* *}$ & 1.000 & $0.465^{* *}$ & $0.428^{* *}$ & $-0.248^{* *}$ & -0.058 & -0.291 ** \\
\hline & $\begin{array}{c}\text { Sig. } \\
\text { (2-tailed) }\end{array}$ & 0.000 & 0.000 & . & 0.000 & 0.000 & 0.000 & 0.332 & 0.000 \\
\hline \multirow[t]{2}{*}{$\begin{array}{l}\text { Lack of } \\
\text { electronic } \\
\text { devices }\end{array}$} & $\begin{array}{l}\text { Correlation } \\
\text { Coefficient }\end{array}$ & $0.400^{* *}$ & $0.378^{* *}$ & $0.465^{* *}$ & 1.000 & $0.364^{* *}$ & $-0.212 * *$ & -0.125 * & $-0.278^{* *}$ \\
\hline & $\begin{array}{c}\text { Sig. } \\
\text { (2-tailed) }\end{array}$ & 0.000 & 0.000 & 0.000 & . & 0.000 & 0.000 & 0.036 & 0.000 \\
\hline
\end{tabular}


Table 3. Cont.

\begin{tabular}{|c|c|c|c|c|c|c|c|c|c|}
\hline & & Fatigue & $\begin{array}{l}\text { Lack of } \\
\text { Human } \\
\text { Interaction }\end{array}$ & $\begin{array}{c}\text { Poor } \\
\text { Internet } \\
\text { Connection }\end{array}$ & $\begin{array}{l}\text { Lack of } \\
\text { Electronic } \\
\text { Devices }\end{array}$ & $\begin{array}{l}\text { Lack of Digital } \\
\text { Proficiency with } \\
\text { Reference to the } \\
\text { Teaching Staff }\end{array}$ & $\begin{array}{c}\text { (Proper) } \\
\text { Instruction }\end{array}$ & $\begin{array}{c}\text { Lack of } \\
\text { Conditions } \\
\text { of Partici- } \\
\text { pation in } \\
\text { Class Time }\end{array}$ & $\begin{array}{c}\text { Clarity of } \\
\text { Duties }\end{array}$ \\
\hline \multirow[t]{2}{*}{$\begin{array}{l}\text { Lack of } \\
\text { digital } \\
\text { proficiency } \\
\text { with } \\
\text { reference to } \\
\text { the teaching } \\
\text { staff }\end{array}$} & $\begin{array}{l}\text { Correlation } \\
\text { Coefficient }\end{array}$ & 0.386 ** & 0.453 ** & 0.428 ** & $0.364^{* *}$ & 1.000 & $-0.321^{* *}$ & -0.003 & $-0.371^{* *}$ \\
\hline & $\begin{array}{c}\text { Sig. } \\
\text { (2-tailed) }\end{array}$ & 0.000 & 0.000 & 0.000 & 0.000 & . & 0.000 & 0.955 & 0.000 \\
\hline \multirow[t]{2}{*}{$\begin{array}{c}\text { (Proper) } \\
\text { Instruction }\end{array}$} & $\begin{array}{l}\text { Correlation } \\
\text { Coefficient }\end{array}$ & $-0.303^{* *}$ & $-0.334^{* *}$ & $-0.248^{* *}$ & $-0.212^{* *}$ & $-0.321^{* *}$ & 1.000 & -0.053 & $0.509^{* *}$ \\
\hline & $\begin{array}{c}\text { Sig. } \\
\text { (2-tailed) }\end{array}$ & 0.000 & 0.000 & 0.000 & 0.000 & 0.000 & . & 0.372 & 0.000 \\
\hline \multirow[t]{2}{*}{$\begin{array}{c}\text { Lack of } \\
\text { conditions of } \\
\text { participation } \\
\text { in class time }\end{array}$} & $\begin{array}{l}\text { Correlation } \\
\text { Coefficient }\end{array}$ & -0.065 & -0.031 & -0.058 & -0.125 * & -0.003 & -0.053 & 1.000 & 0.048 \\
\hline & $\begin{array}{c}\text { Sig. } \\
\text { (2-tailed) }\end{array}$ & 0.280 & 0.604 & 0.332 & 0.036 & 0.955 & 0.372 & . & 0.421 \\
\hline \multirow[t]{2}{*}{$\begin{array}{c}\text { Clarity of } \\
\text { duties }\end{array}$} & $\begin{array}{l}\text { Correlation } \\
\text { Coefficient }\end{array}$ & $-0.383^{* *}$ & $-0.287^{* *}$ & $-0.291 * *$ & $-0.278^{* *}$ & $-0.371^{* *}$ & 0.509 ** & 0.048 & 1.000 \\
\hline & $\begin{array}{c}\text { Sig. } \\
\text { (2-tailed) }\end{array}$ & 0.000 & 0.000 & 0.000 & 0.000 & 0.000 & 0.000 & 0.421 & . \\
\hline
\end{tabular}

**. Correlation is significant at the 0.01 level (2-tailed). *. Correlation is significant at the 0.05 level (2-tailed).

\section{Discussion}

The SARS-Cov-2 pandemic has confronted us with certain unprecedented professional reconfigurations irrespective of the domain in which we work. Certain fields of work are better prepared for telecommuting than others. In Romania, telecommuting in the education sphere or digital schooling was subjected to significant challenges. The study of the situation of online education is extremely important for understanding the impact that this has had on the level of the didactic process and content delivery, but also at the level of society as a whole because facing the challenges of the pandemic can help the education system embrace the health situation as a set of opportunities for building a sustainable online education in Romania. Although some have the impression that our duties have been fulfilled as teachers and as students, things are more nuanced than that. Challenges like fatigue and the unclarity of duties, the need for human interaction, poor internet connection, boredom, the lack of motivation, unfit work conditions at home or of various devices are just a few of the problems that were subject to validation or invalidation in the course of our study as opportunities for the drafting and implementation of a sustainable online education system. In light of these factual aspects of online education in the context of the SARS-Cov-2 pandemic, the goal of this article is to draft concrete solutions for telecommuting across the school system not only by turning the current challenges into possible opportunities but also by identifying some practical implications for a realistically sustainable online education.

Thus, as a result of the correlation analyses, $\mathrm{H} 1$ is accepted, the results revealing a statistically significant negative correlation $\left(-0.383^{* *}\right)$ between the fatigue felt by students during online classes and the clarity of their tasks. Similar findings were shown by the authors of [15] on a sample of students from the United States, those of [16] on a sample of students from Indonesia, of [17] on a sample of students in Turkey: all this research shows a similar degree of negative correlation, accepting this issue.

The second hypothesis, $\mathrm{H} 2$, is also accepted, the connection between the lack of human interaction and the clarity of tasks likewise being statistically significant and negative $\left(-0.287^{* *}\right)$. Comparing this result with the research of other authors, similar results can 
be identified, as in the questionnaire applied to teachers in India [12], respectively, in the analysis performed by the authors of [14], which identifies several possibilities for asynchronous correlations in the distribution of tasks generated by telework in higher education. Moreover, a study edited by the authors [5] shows that an important sample of students from Chinese Southeast University considers that the reduplication of traditional learning by online learning is not viable and feasible, mostly because the lack of human presence cannot control the pace of learning and it results in poor feedback regarding the completion of homework or evaluations.

Poor internet connection also has a negative impact on the clarity of tasks, so that $\mathrm{H} 3$ is also accepted on the grounds that the two variables are negatively correlated in a statistically significant way $\left(-0.291^{* *}\right)$. Analyzing the literature, there are many researchers who have mentioned this hypothesis in their research, such as Dube (2020) and introspection in rural South Africa, [14] in the Philippines, and other extensive research in Asian or African countries [34,35,51]. Internet connectivity problems were seen by the authors of [12] as an important liability in the transition from traditional learning towards online learning, in a questionnaire circulated among professors from Indian universities who shifted to virtual classes and those who have not.

The lack of devices also has a role in the reduction of the clarity of tasks, the two variables being negatively correlated in a statistically significant way $\left(-0.278^{* *}\right)$, which makes $\mathrm{H} 4$ acceptable. Similar results were obtained by the authors of [15] in an extensive study in the United States. The hypothesis is more obvious when applied to areas that are generally well known for lacking proper information technologies equipment and services, like some countries from the African and Asian continents [32,34,35].

There is also such a statistically significant negative correlation between the lack of digital competency of educators and the clarity of tasks, which makes $\mathrm{H} 5$ acceptable $\left(-0.371^{* *}\right)$, hypothesis mentioned in the research of $[9,10]$, with similar results. Other authors [9] insist on this issue of the focus group method and create a profile of the digital teacher. Some researchers [11] went even further in demonstrating that telecommuting had an important influence on the training of professors and would most likely earn the status of an innovative method in pedagogy. There is quite a radical vision [9] that builds on the idea that minor improvements or no improvements at all in the 'digital conduct' of professors would lead to their replacement by robotic teachers. Furthermore, a panel of experts from American universities [29] reveals that online teaching automatically generates multi-purpose roles for professors, such as facilitators, course designers, content managers, and most importantly, mentors.

There is a strong connection between the instruction of students and the clarity of tasks, one that is statistically significant and positive $\left(0.509^{* *}\right)$ — strong correlation so that H6 is accepted. This hypothesis is found in the literature under the name of self-teaching of students in the online environment, as formulated and demonstrated by the authors of [7], in the same note being the results of applying a questionnaire on a large sample of students in China [6], which identifies students' dissatisfaction with the lack of input and feedback for course topics, respectively for ongoing assessments.

$\mathrm{H} 7$ is rejected on the basis of a lack of statistically significant connection between the lack of participatory online conditions and the clarity of tasks. Moreover, researchers [25,28,52] showed that the conditions of accessibility and autonomy of students became much more favorable with the introduction of online teaching, for obvious reasons of lack of money, time, and availability to travel which all hold the prospect of sustainability as a real possibility for online education.

\section{Conclusions}

The impact that online education has had will first have many answers over time that will not help to understand even more the complexity of this phenomenon. We consider it important to specify at the end of this that in the absence of a health crisis, we believe that the impact and implications of online school would have generated other research routes. Elements such as fatigue, anxiety, lack of an adequate tools, lack of niche digital skills, 
poor familiarity with e-learning platforms, lack of adequate devices for online education were in fact established measures taken against the SARS-COV-2 virus, so they do not automatically cancel the prospect of sustainability and efficiency for online education.

These elements that have affected the understanding of educational activities warn that beyond the advantages of online education, it has major disadvantages in terms of substance, content, and school skills, that is, it reaches the very essence of education. This research highlights some limitations but also opens important future research perspectives that we intend to start in the next period.

For example, interesting and extremely relevant would be comparative research on large fields of study (human, real, vocational, technical, etc.) or special education or on the need for a support teacher in online education for those with special problems. In another order of ideas, but not far from the previous one, in order to complete the picture with angles and perspectives that can give weight and scientific legitimacy to the whole topic of online education, it is also necessary to approach access to online education for disadvantaged backgrounds (the rural environment disadvantaged due to poor signal coverage, etc.). These particular cases hold inherent sustainability for online education, the application of which will have to be discussed more in terms of efficiency.

Paradoxically, although online school offers a priori equal access to all, the poor signal coverage in some areas and the lack of devices make access to education only for some. If before SARS-COV-2 with a pen and a notebook you could have access to education, today you need a whole technological-digital aggregate and that does not guarantee access to the school's mission: learning and skilling with information. In the present analysis, we have tried to identify which are the elements that contribute to the ambiguity of tasks and all that they involve, none of which are indications that online education lacks sustainability.

Obstructions that lead to an unclear educational act—in the fog, profoundly affect the learning and content fixation process. Of the seven hypotheses proposed and submitted to research, six were validated. The launched hypotheses received validation from two directions: both through other researchers (review of the literature) and through quantitative research: the questionnaire. Beyond the limitations of this study, mentioned below, our research aimed and largely managed to interrogate and come up with scientifically well-argued answers about the act and implication that the online school has. Beyond the proposed and achieved desideratum, we managed to identify important and serious directions of future research, which confirm that online education can be not only sustainable but also efficient, at least to some considerable degree despite the challenges presented here.

Among the future research directions, we also mention the intention of a comparative analysis between the school results during the pandemic when it was mainly online school and the school results after returning to school. The comparative analysis will be correlated with a focus group with teachers to ensure that the assessment during the online school did not suffer and did not have elements of situational indulgence.

\subsection{Study Limitations}

The authors have identified two limitations of this study: (1) the fact that the questionnaire is based exclusively on responses from Romanian students (the situation of online education may be different in advanced economies as opposed to emergent economies), and (2) the questionnaire aimed at focusing on the situation of students and their perceptions, NOT professors (an inquiry investigating the professors' perception of online education may change the final results and the conclusions of this study).

\subsection{Practical Implications}

In light of the results and conclusions of this study, the authors envision a set of three practical implications: (1) the context of online education must be adjusted to the new realities of the current pandemic (or future similar medical events) and such adjustments cannot be done in the absence of sustained government support; (2) both students and 
professors need to be trained so that online education no longer appears as limiting or threatening but rather beneficial and welcoming (government authorities might well decide to include specific classes about how online education should/could be appropriated as a normal educational activity), and (3) government policies must take into account the possibility of future pandemic events which must result in a thorough readjustment of educational policies across the whole range of educational institutions (from kindergarten to postdoctoral activities).

Author Contributions: Conceptualization, Methodology, Software, Validation, Formal analysis, Investigation, Resources, Data curation, Writing - original draft preparation, Writing-review and editing, Visualization, Supervision, Project administration, Funding acquisition: C.C.S., L.P., F.-A.P. and I.M.O. All authors have read and agreed to the published version of the manuscript.

Funding: Paper funded by Project 123008, “SmartDoct-High quality programs for doctoral students and postdoctoral researchers of the University of Oradea to increase the relevance of research and innovation in the context of the regional economy", project funded by the Human Capital Program 2014-2020.

Conflicts of Interest: The authors declare no conflict of interest. The funders had no role in the design of the study; in the collection, analyses, or interpretation of data; in the writing of the manuscript, or in the decision to publish the results.

\section{References}

1. Bento, F.; Couto, K.C. A Behavioral Perspective on Community Resilience during the COVID-19 Pandemic: The Case of Paraisopolis in Sao Paulo, Brasil. Sustainability 2021, 13, 1447. [CrossRef]

2. Joia, L.A.; Michelotto, F. Universialists or Utilitarianists? The Social Representation of COVID-19 Pandemic in Brazil. Sustainability 2020, 12, 10434. [CrossRef]

3. Kulikowski, K.; Przytuła, S.; Sułkowski, Ł. The Motivation of Academics in Remote Teaching during the Covid-19 Pandemic in Polish Universities-Opening the Debate on a New Equilibrium in e-Learning. Sustainability 2021, 13, 2752. Available online: https: / / www.mdpi.com/2071-1050/13/5/2752/htm (accessed on 1 June 2021). [CrossRef]

4. Obrad, C. Constraints and Consequences of Online Teaching. Sustainability 2020, 12, 6982. [CrossRef]

5. Sun, L.; Yongming, T.; Wei, Z. Coronavirus pushes education online. Nat. Mater. 2020, 19, 687. Available online: https: //www.nature.com/articles/s41563-020-0678-8.pdf (accessed on 1 March 2021). [CrossRef] [PubMed]

6. Zhou, L.; Shanshan, W.; Zhou, M.; Fangmei, L. 'School's Out, But Class' On', The Largest Online Education in the World Today: Taking China's Practical Exploration During The COVID-19 Epidemic Prevention and Control as an Example. Best Evid. Chin. Edu. 2020, 4, 501-519. Available online: https:/ / papers.ssrn.com/sol3/papers.cfm?abstract_id=3555520 (accessed on 15 March 2021). [CrossRef]

7. Bao, W. COVID-19 and online teaching in higher education: A case study of Peking University. Hum. Behav. Emerg. Technol. 2020, 2,113-115. Available online: https:/ / onlinelibrary.wiley.com/doi/full/10.1002/hbe2.191 (accessed on 1 March 2021). [CrossRef] [PubMed]

8. Hodges, C.; Moore, S.; Lockee, B.; Trust, T.; Bond, A. The Difference between Emergency Remote Teaching and Online Learning. Educ. Rev. 2020. Available online: http://www.cetla.howard.edu/workshops/docs/The\%20Difference $\% 20$ Between $\% 20$ Emergency\%20Remote\%20Teaching\%20and\%20Online\%20Learning\%20_\%20EDUCAUSE\%20(2).pdf (accessed on 1 March 2021).

9. Ally, M. Competency Profile of the Digital and Online Teacher in Future Education. Int. Rev. Res. Open Distrib. Learn. 2019, 20. Available online: https:/ / www.erudit.org/en/journals/irrodl/2019-v20-n2-irrod104703/1061343ar.pdf (accessed on 15 March 2021). [CrossRef]

10. Jinyoung, K. Learning and Teaching Online During Covid-19: Experiences of Student Teachers in an Early Childhood Education Practicum. Int. J. Early Child. 2020, 52, 145-158. Available online: https:/ /link.springer.com/content/pdf/10.1007/s13158-020-0 0272-6.pdf (accessed on 15 March 2021).

11. Dooly, M.; Sadler, R. "If you don't improve, what's the point?" Investigating the impact of a "flipped" online exchange in teacher education. ReCALL 2019, 32, 4-24. Available online: https://www.cambridge.org/core/journals/recall/article/if-youdont-improve-whats-the-point-investigating-the-impact-of-a-flipped-online-exchange-in-teacher-education/249D10EE952 6CABE8996E7A00ED69DAA (accessed on 15 March 2021). [CrossRef]

12. Arora, A.K.; Srinivasan, R. Impact of Pandemic COVID-19 on the Teaching-Learning Process: A Study of Higher Education Teachers. Prabandhan Indian J. Manag. 2020, 13, 43-56. Available online: http:/ / indianjournalofmanagement.com/index.php/ pijom/article/view/151825 (accessed on 1 March 2021). [CrossRef]

13. Wasserman, E.; Migdal, R. Professional Development: Teachers' Attitudes in Online and Traditional Training Courses. Online Learn. 2019, 23, 132-143. Available online: https://files.eric.ed.gov/fulltext/EJ1211174.pdf (accessed on 15 March 2021). [CrossRef] 
14. Van Wart, M.; Ni Anna, R.L.; McWeeney, T.; Worrell, R. A Literature Review and Model of Online Teaching Effectiveness Integrating Concerns for Learning Achievement, Student Satisfaction, Faculty Satisfaction, and Institutional Results. J. Bus. Res. 2019, 10, 1-22. Available online: http:/ / ppbri.com/Journals/2019/PPJBR\%202019\%20Spring\%20(1)\%20revised.pdf (accessed on 1 March 2021).

15. Garris, C.; Fleck, B. Student evaluations of transitioned-online courses during the COVID-19 pandemic. Scholarsh. Teach. Learn. Psychol. 2020, 1-21. Available online: https:/ / psycnet.apa.org/fulltext/2020-77535-001.pdf (accessed on 15 March 2021). [CrossRef]

16. Irawan, A.; Dwisona, W.; Lestari, M. Psychological Impacts of Students on Online Learning During the Pandemic COVID-19. KONSELI J. Bimbigan Konseling 2020, 7, 53-60. Available online: http://ejournal.radenintan.ac.id/index.php/konseli/article/ view /6389/3564 (accessed on 15 March 2021). [CrossRef]

17. Herguner, G.; Bugra, S.; Herguner, S.; Donmez, A. The Effect of Online Learning Attitudes of University Students on Their Online Learning Readiness. Turk. Online J. Educ. Technol. 2020, 19, 102-110. Available online: https://files.eric.ed.gov/fulltext/EJ12728 71.pdf (accessed on 1 March 2021).

18. García-Peñalvo, F.J.; Corell, A.; Abella-García, V.; Grande-de-Prado, M. Recommendations for Mandatory Online Assessment in Higher Education during the COVID-19 Pandemic. In Radical Solutions for Education in a Crisis Context; Springer: Singapore, 2020; pp. 85-98. Available online: https://link.springer.com/content/pdf/10.1007\%2F978-981-15-7869-4_6.pdf (accessed on 1 March 2021).

19. Basilaia, G.; Kvavadze, D. Transition to Online Education in Schools during a SARS-CoV-2 Coronavirus (COVID-19) Pandemic in Georgia. Pedagog. Res. 2020, 5. Available online: https:/ / files.eric.ed.gov/fulltext/EJ1263561.pdf (accessed on 15 March 2021). [CrossRef]

20. Sahu, P. Closure of Universities due to Coronavirus Disease 2019 (COVID-19): Impact on Education and Mental Health of Students and Academic Staff. Cureus 2020, 12. Available online: https://www.ncbi.nlm.nih.gov/pmc/articles/PMC7198094/ (accessed on 15 March 2021). [CrossRef]

21. Murphy, M. COVID-19 and emergency eLearning: Consequences of the securitization of higher education for post-pandemic pedagogy. Contemp. Secur. Policy 2020, 41, 492-505. Available online: https://www.tandfonline.com/doi/full/10.1080/13523260 .2020.1761749? scroll=top\&needAccess=true (accessed on 1 March 2021). [CrossRef]

22. Bilen, E.; Matros, A. Online cheating amid COVID-19. J. Econ. Behav. Organ. 2021, 182, 196-211. Available online: https:/ / reader.elsevier.com/reader/sd/pii/S0167268120304510?token=d567fdc11affdfd993b8efe624b5b08b7c22513b551695067 bc71aa3ef6720fcb6141133b17526701535b693389845e7 (accessed on 1 March 2021). [CrossRef]

23. Daniel, J. Education and the COVID-19 pandemic. Prospects 2020, 49, 91-96. Available online: https://link.springer.com/content/ pdf/10.1007/s11125-020-09464-3.pdf (accessed on 15 March 2021). [CrossRef]

24. Syauqi, K.; Munadi, S.; Triyono, M.B. Students' Perceptions toward Vocational Education on Online Learning during the COVID-19 Pandemic. Int. J. Eval. Res. Educ. 2020, 9, 881-886. Available online: https://files.eric.ed.gov/fulltext/EJ1274581.pdf (accessed on 15 March 2021).

25. Protopsaltis, S.; Baum, S. Does Online Education Live Up to Its Promise? A Look at the Evidence and Implications for Federal Policy. Available online: https://jesperbalslev.dk/wp-content/uploads/2020/09/OnlineEd.pdf (accessed on 1 March 2021).

26. Zhu, X.; Jing, L. Education in and After Covid-19: Immediate Responses and Long-Term Visions. Postdigital Sci. Educ. 2020, 2, 695-699. Available online: https:/ /link.springer.com/content/pdf/10.1007/s42438-020-00126-3.pdf (accessed on 1 March 2021). [CrossRef]

27. Muhammad, A.; Kainat, A. Online Learning amid the COVID-19 Pandemic: Students' Perspectives. J. Pedagog. Sociol. Psychol. 2020, 2, 45-51. Available online: https:/ / files.eric.ed.gov / fulltext/ED606496.pdf (accessed on 1 March 2021).

28. Rapanta, C.; Botturi, L.; Goodyear, P.; Guàrdia, L.; Koole, M. Online University Teaching during and after the Covid-19 Crisis: Refocusing Teacher Presence and Learning Activity. Postdigital Sci. Educ. 2020, 2, 923-945. Available online: https: / /link.springer.com/content/pdf/10.1007/s42438-020-00155-y.pdf (accessed on 1 March 2021). [CrossRef]

29. Martin, F.; Budhrani, K.; Kumar, S.; Ritzhaupt, A. Award-Winning Faculty Online Teaching Practices: Roles and Competencies. Online Learn. 2019, 23, 184-205. Available online: https: / / files.eric.ed.gov/fulltext/EJ1211042.pdf (accessed on 1 March 2021). [CrossRef]

30. Williamson, B.; Eynon, R.; Potter, J. Pandemic politics, pedagogies and practices: Digital technologies and distance education during the coronavirus emergency. Learn. Media Technol. 2020, 45, 107-114. Available online: https://www.tandfonline.com/doi/ full/10.1080/17439884.2020.1761641?scroll=top\&needAccess=true (accessed on 15 March 2021). [CrossRef]

31. Dhawan, S. Online Learning: A Panacea in the Time of COVID-19 Crisis. J. Educ. Technol. 2020, 49, 5-22. Available online: https:/ /journals.sagepub.com/doi/pdf/10.1177/0047239520934018 (accessed on 1 March 2021).

32. Dube, B. Rural online learning in the context of COVID 19 in South Africa: Evoking an inclusive education approach. Multidiscip. J. Educ. Res. 2020, 10, 135-157. Available online: https://www.hipatiapress.com/hpjournals/index.php/remie/article/view/56 $07 /$ pdf (accessed on 1 March 2021). [CrossRef]

33. Toquero, C.M. Challenges and Opportunities for Higher Education Amid the COVID-19 Pandemic: The Philippine Context. Pedagog. Res. 2020, 5, 1-5. Available online: https://files.eric.ed.gov/fulltext/EJ1263557.pdf (accessed on 1 March 2021). [CrossRef] 
34. Bozkurt, A.; Insung, J.; Junhong, X.; Vladimirschi, V.; Schuwer, R.; Gennady, E.; Sarah, R.L.; Maha, A.F.; Pete, J.; Don, O.; et al. A global outlook to the interruption of education due to COVID-19 Pandemic: Navigating in a time of uncertainty and crisis. Asian J. Distance Educ. 2020, 15, 1-126. Available online: http://www.asianjde.org/ojs/index.php/AsianJDE/article/view/462/307 (accessed on 1 March 2021).

35. Marinoni, G.; van't Land, H.; Jensen, T. The impact of COVID-19 on Higher Education around the World. In IAU Global Survey Report; International Association of Universities: Paris, France, 2020; Available online: https://www.iau-aiu.net/IMG/pdf/iau_ covid19_and_he_survey_report_final_may_2020.pdf (accessed on 15 March 2021).

36. Gail, M.S.; Anthony, R.A. Analyzing and Interpreting Data From Likert-Type Scales. J. Grad. Med. Educ. 2013, 5, 541-542. Available online: https://www.ncbi.nlm.nih.gov/pmc/articles/PMC3886444/ (accessed on 1 June 2021).

37. Vereștiuc, S. Cele 7 Probleme Majore Ale Școlii Online. Available online: https://ziare.com/scoala/stiri-invatamant/cepresupune-scoala-online-care-sunt-problemele-si-ce-solutii-exista-1639259 (accessed on 1 March 2021).

38. Popovici, V.; Bujoreanu, S. Ce Probleme au Întâmpinat Elevii și Studenții cu Școala Online. Câteva Observații și Sugestii Pentru Autorități Stânse Din Țară. Available online: https://www.hotnews.ro/stiri-educatie-23788925-spun-elevii-studentii-desprecursurile-online-din-timpul-pandemiei-coronavirus.htm (accessed on 1 March 2021).

39. Lazar, A.; Hatos, A. Religiosity and Generosity of Youth. The Results of a Survey conducted on 8th Grade Students from Bihor County (Romania). Rev. Rom. Pentru Educ. Multidimens. 2019, 11, 93-118.

40. Hatos, A. Serving the New Class: The Dynamics of Educational Transitions for Romanian Adults Born before 1985 during Communism and Afterwards. Soc. Indic. Res. 2014, 119, 1699-1729. Available online: https://www.jstor.org/stable/24721509 ?fbclid=IwAR2UXFL10ZmJfPNU7-GX9XJOMO6ExsKqbmAW8mmpSxoa2aP2Bg99b8ExcsE (accessed on 5 May 2021). [CrossRef]

41. Hatos, A. Clientele vs. Status Seeking? Subject Field Choice in Higher Education in the Hungarian-Romanian Cross-Border Region. Rev. Cercet. Interv. Soc. 2017, 59, 153-168.

42. Petrescu, M. Cum a Mers Învățământul Online în ROMÂNIA în Timpul Pandemiei. Probleme și Soluții. Available online: https: //www.contributors.ro/cum-a-mers-invatamantul-online-in-romania-in-timpul-pandemiei-probleme-si-solutii/ (accessed on 15 March 2021).

43. Cum Văd Elevii Începutul Anului Școlar 2020-2021. Raport Sumativ Privind Debutul Anului Școlar 2020-2021 Din Perspectiva Elevilor. Available online: https:/ / consiliulelevilor.ro/wp-content/uploads/2015/10/Raport-sumativ-privind-debutul-anului\%C8\%99colar-2020-2021-din-perspectiva-elevilor.pdf (accessed on 15 March 2021).

44. Cea Mai Mare Problemă a Elevilor la Școala Online: Lipsa Competențelor Digitale ale Profesorilor. Available online: https: / /romania.europalibera.org/a/lipsa-competen \%C8\%9Belor-digitale-ale-profesorilor-o-problem $\%$ C4\%83-reclamat $\%$ C4 \%83-de-elevi/30767837.html (accessed on 1 March 2021).

45. Hatos, A.; Băltățescu, S. Family Structure and School Results: Multivariate Analysis of Answers of Teenage Students in a Romanian City. Child Indic. Res. 2013, 6, 281-295. Available online: https://link.springer.com/article/10.1007\%2Fs12187-0 12-9169-z?fbclid=IwAR0x4P1pTaTI6RHED6xK1wxeOk9tA-cSzs0sAEhA_PvNgTuNdkzKFslVS3w (accessed on 14 April 2021). [CrossRef]

46. Lazar, A.; Hatos, A. European Philanthropic Behavior Patterns: Charitable Giving, Non-Profit and Welfare Regimes in the European Union. Transilv. Rev. Adm. Sci. 2019, 15, 21-40. [CrossRef]

47. Paraschiv, L. Efectele Școlii Online. Expert în Educație: Cele Mai Mari Probleme Le-Ar Putea Avea Elevii Din Clasele a Șasea și a Saptea. Available online: https:/ / www.mediafax.ro/social/efectele-scolii-online-expert-in-educatie-cele-mai-mari-problemele-ar-putea-avea-elevii-din-clasele-a-sasea-si-a-saptea-19749833 (accessed on 1 March 2021).

48. Mușat, O. Ce Probleme Întâmpină Profesorii în Școala Online: Asigurarea Accesului Egal la Educație, Lipsa Competențelor Digitale și Siguranța Online. Available online: https:/ /www.observatordetimis.ro/2020/10/14/ce-probleme-intampina-profesorii-in-scoalaonline-asigurarea-accesului-egal-la-educatie-lipsa-competentelordigitale-si-siguranta-online/ (accessed on 15 March 2021).

49. Nemțeanu, M.S.; Dabija, D.C. The Influence of Internal Marketing and Job Satisfaction on Task Performance and Counterproductive Work Behavior in an Emerging Market during the COVID-19 Pandemic. Int. J. Environ. Res. Public Health 2021, $18,3670$. [CrossRef] [PubMed]

50. Nemțeanu, M.S.; Dinu, V.; Dabija, D.C. Job Insecurity, Job Instability, and Job Satisfaction in the Context of the COVID-19 Pandemic. J. Compet. 2021, 13, 65-82. [CrossRef]

51. Reimers, F.; Schleicher, A. A Framework to Guide an Education Response to the COVID-19 Pandemic of 2020; OECD: Paris, France, 2020; Available online: https:/ / oecd.dam-broadcast.com/pm_7379_126_126988-t63lxosohs.pdf (accessed on 15 March 2021).

52. Wahab, A. Online and Remote Learning in Higher Education Institutes: A Necessity in Light of COVID-19 Pandemic. High. Educ. Stud. 2020, 10, 16-25. Available online: https:/ / files.eric.ed.gov/fulltext/EJ1259642.pdf (accessed on 15 March 2021). 